\title{
COPD Patients or 'Healthy Smokers': Is IL-8 Synthesis and Release the Borderline?
}

\author{
Giovanni A. Rossi \\ Pulmonary and Allergy Unit, G. Gaslini Institute, Genoa, Italy
}

Chronic obstructive pulmonary disease (COPD) is characterized by structural changes in the central and peripheral airways producing irreversible, progressive obstruction of expiratory flow [1]. The pathological changes characteristic of COPD include inflammation of the large and small airways, enlarged mucus secreting glands with an increased number of goblet cells and mucus hypersecretion, structural remodeling of the airway wall, with increased collagen content and scar tissue formation, and, finally, dilatation and destruction of the respiratory bronchioles [1].

Recent studies have greatly improved our understanding of the pathogenetic mechanisms underlying COPD [1, 2]. Indeed, it has been demonstrated that persistent airway inflammation is characterized not only by high numbers of neutrophils but also by the presence of activated macrophages and T-lymphocytes (predominant CD8+) [1-3]. These immunoeffector cells release a variety of mediators, including leukotriene $\mathrm{B}_{4}\left(\mathrm{LTB}_{4}\right)$, interleukin-8 (IL-8), and tumour necrosis factor- $\alpha$ (TNF- $\alpha$ ), capable of sustaining the neutrophilic inflammation that characterizes the disease $[3,4]$. The recruitment and activation of neutrophils lead to the production of large amounts of toxic oxygen radicals and to the release of granule-associated preformed enzymes $[2,4]$. The resulting oxidative stress and proteinase-antiproteinase imbalance is a key factor in inducing the chronic injury to the lung parenchymal cells and the destruction of the airway structures described in COPD patients [1,2].

The inflammatory process within the lungs is thought to be caused and maintained by environmental exposure to inhaled noxious particles and gases in subjects genetically predisposed to develop the disease. Although occupational dusts and chemicals and outdoor and indoor air pollutants may play a relevant role, cigarette smoking is considered the major factor involved in the pathogenesis of COPD [2]. Indeed, cigarette smoke can not only induce activation of inflammatory mechanisms and directly damage the lungs but also adversely affect the repair mechanisms activated in response to this injury.

Insufficient repair of alveolar structures leads to emphysema with destruction of alveolar attachments, while repair with scarring is likely to lead to irreversible and progressive airflow limitation [1,2]. Active smokers have a higher prevalence of lung function abnormalities and respiratory symptoms, a greater annual rate of decline in $\mathrm{FEV}_{1}$, and higher death rates for COPD than nonsmokers [5], but also passive exposure to cigarette smoke, increasing lung total burden of inhaled particulates and gases, may contribute to respiratory structure injury [6].

\begin{tabular}{ll}
\hline KARGER & (c) 2003 S. Karger AG, Basel \\
Fax +4161306 1234 & 0025-7931/03/0705-0457\$19.50/0 \\
$\begin{array}{l}\text { E-Mail karger@karger.ch } \\
\text { www.karger.com }\end{array}$ & $\begin{array}{l}\text { Accessible online at: } \\
\text { www.karger.com/res }\end{array}$
\end{tabular}

Giovanni A. Rossi, MD
Pulmonary and Allergy Unit, G. Gaslini Institute, Largo G. Gaslini, 5
IT-16147 Genoa (Italy)
Tel. +39 0105636547 , Fax +39 0103776590
E-Mail giovannirossi@ospedale-gaslini.ge.it 
Only a minority of smokers, however, develop clinically relevant airway disease. This suggests that, in addition to environmental exposures, genetic factors should be also involved in increasing or decreasing each individual's risk of having COPD $[1,7]$.

Epidemiological models have been designed to identify 'susceptible' smokers, evaluating with different results type of exposure to cigarette smoke and/or to other inhalant pollutants, presence of respiratory viral infection in early life, differences in nutrition that could play a protective role against oxidative stress [1,7]. Because of the inconclusive results of these models, genetic differences are considered the most likely factors leading to 'susceptibility' to disease. The only proven genetic risk factor for COPD is a relatively rare hereditary disorder interfering with the synthesis and/or the release of $\alpha_{1}$-antitrypsin, the major antiprotease within the lung [8]. Premature and accelerated development of panlobular emphysema and decline in lung function occur in subjects with the severe forms of $\alpha_{1}$-antitrypsin deficiency, and there is no doubt that cigarette smoking increases the risk appreciably $[8$, 9]. However, since $\alpha_{1}$-antitrypsin-deficient subjects exhibit wide variability in pulmonary function impairment, even when having a similar smoking history, other genes should also be involved.

Candidate genes may include those encoding for $\alpha_{1}$ antichymotrypsin, vitamin-D-binding protein, $\alpha_{2}$-macroglobulin, immunoglobulins, extracellular superoxide dismutase, secretory leukocyte proteinase inhibitor, cathep$\sin$ G, TNF- $\alpha$ [7-9]. However, a variety of host factors related to the modulation of the inflammatory and repair processes may affect various pathways of COPD pathogenesis, and this genetic heterogeneity is likely to contribute to the difficulty in replicating associations between studies and may explain why most tests on genetic differences have led to inconsistent results leaving the question open $[8,9]$.

In a recent issue of Respiration, Schultz et al. [10] suggest that one difference between COPD patients and 'healthy smokers' could be related to the amount of IL-8 synthesized and released by airway epithelial cells, constitutively or in response to TNF- $\alpha$, an inflammatory cytokine found in the respiratory secretion of COPD patients.

Being a chemokine of the C-X-C subfamily, IL-8 is one of the most potent neutrophil 'activators', since it is able to upregulate adhesion molecule expression on their surface, to enhance $\mathrm{LTB}_{4}$ and 5-hydroxyeicosatetraenoic acid (5-HETE) production, to induce neutrophil chemotaxis, and to increase their adherence to endothelial cells and epithelial cells [11]. IL-8 has been shown to account for a significant amount of neutrophil sequestration in a variety of human diseases [11] and this may be true also for COPD. Indeed, cigarette smoke extract is highly effective in stimulating IL-8 release from bronchial epithelial cells in vitro and increased levels of IL-8 mRNA and/or protein have been measured in bronchiolar walls, alveolar epithelium and airway secretion of COPD patients, with further increases during disease exacerbations $[4,12,13]$.

In addition to epithelial cells [14], monocytes, macrophages and neutrophils are major cellular sources for IL-8 in the lung, since they produce large amounts of this chemokine after stimulation with organic and inorganic particles, bacteria and antigens $[11,15]$. All these cell types are activated in COPD patients $[1,3,16]$ and it would be extremely interesting to prove that the differences in IL-8 synthesis and secretion between COPD patients and 'healthy smokers', shown by Schultz et al. [10], are not limited to airway epithelial cells. The fascinating hypothesis that the 'borderline' between COPD patients and 'healthy smokers' could be related to genetic or acquired differences in cell activation pathways leading to proinflammatory mediator synthesis and release, could open up new areas of research on the individual predisposition to develop chronic airway diseases and on the potential for anticytokine therapy in these patients. 


\section{References}

1 Global Initiative for Chronic Obstructive Lung Disease (GOLD). US NIH Publication No. 2701A, March 2001.

2 Rennard SI: Overview of causes of COPD. New understanding of pathogenesis and mechanisms can guide future therapy. Postgrad Med 2002;11:33-34.

3 Fabbri LM, Romagnoli M, Corbetta L, Casoni G, Busiljetic K, Turaro G, Ligabue G, Ciaccia A, Saetta M, Papi A: Differences in airway inflammation in patients with fixed airflow obstruction due to asthma or chronic obstructive pulmonary disease. Am J Respir Crit Care Med 2003;167:418-424.

4 Chung KF: Cytokine in chronic obstructive pulmonary disease. Eur Respir J 2001;18:34: $50 \mathrm{~s}-59 \mathrm{~s}$.

5 US Surgeon General: The health consequences of smoking: Chronic obstructive pulmonary disease. Washington, US Department of Health and Human Services, 1984, Publication No. 84-50205.

6 Dayal HH, Khuder S, Sharrar R, Trieff N: Passive smoking in obstructive respiratory disease in an industrialized urban population. Environ Res 1994;65:161-171.
7 Siafakas NM, Tzortzaki EG: Few smokers develop COPD. Why? Respir Med 2002;96:615624.

8 McElvaney NG, Crystal RG: Inherited susceptibility of the lung to proteolytic injury; in Crystal RG, West JB, Weibel ER, Barnes PJ (eds): The Lung: Scientific Foundations. Philadelphia, Lippincott-Raven, 1997:2537-2553, 1998:823-842.

9 Silverman EK: Genetics of chronic obstructive pulmonary disease. Novartis Found Symp 2001;234:45-58

10 Schultz C, Wolf K, Harth M, Krätzel K, KunzSchughart L, Pfeifer M: Expression and release of interleukin- 8 by human bronchial epithelial cells from patients with chronic obstructive pulmonary disease, smokers, and never-smokers. Respiration 2003;70:254-261.

11 Baggiolini M, Dewald B, Moser B: IL-8 and related chemotactic cytokines-C-X-C and CC chemokines. Adv Immunol 1994;55:97-179.
12 Mio T, Romberger DJ, Thompson AB, Robbins RA, Heires A, Rennard SI: Cigarette smoke induces interleukin-8 release from human bronchial epithelial cells. Am J Respir Crit Care Med 1997;155:1770-1776.

3 De Boer WI, Sont JK, van Schadewijk, Stolk J, van Krieken JH, Hiemstra PS: Monocyte chemoattractant protein 1 , interleukin 8 and chronic airways inflammation in COPD. $\mathrm{J} \mathrm{Pa}-$ thol 2000;190:619-626.

14 Rennard SI, Beckman JD, Robbins RA: Biology of airway epithelial cells; in Crystal RG, West JB (eds): The Lung: Scientific Foundations. Raven Press, New York, 1991, pp 157 167.

15 Bazzoni F, Cassatella MA, Rossi M, Ceska M, Dewald B, Baggiolini M: Phagocytosing neutrophils produce and release high amounts of the neutrophil activating peptide-1/IL-8. J Exp Med 1991;173:771-774.

16 Petrilli FL, Rossi GA, Camoirano A, Romano M, Serra D, Benicelli C, De Flora A, De Flora S: Metabolic reduction of chromium by alveolar macrophages and its relationships to cigarette smoking. J Clin Invest 1986;77:19171924 